\title{
Blood Group Substance-degrading Enzymes Obtained from Streptomyces sp.
}

\author{
Part II. Purification and Characteristics of $\alpha$-Galactosidase \\ from Streptomyces $9917 \mathrm{~S}_{2}$
}

By Kunio Orshi and Ko AIDA

Institute of Applied Microbiology, The University of Tokyo

Received August 31, 1971

\begin{abstract}
The blood group B substance-degrading activity of Streptomyces $9917 \mathrm{~S}_{2}$ is induced by galactosides as $\alpha$-galactosidase activity is. Purification of the $\alpha$-galactosidase was attempted by chromatography on DEAE-Sephadex and Sephadex. The purified preparation was shown to be free from $\alpha$ - and $\beta$-glucosidases, $\beta$-galactosidase, $\alpha$ - and $\beta$-glucosaminidases, and $\alpha$ and $\beta$-galactosaminidases activities. The blood group $B$ substance-degrading activity was present only in this fraction. This enzyme preparation cleaves $\alpha-(1 \rightarrow 3)$ - and $\alpha-(1 \rightarrow 6)$-galactosidic linkages. The activity is inhibited by D-galactose, melibiose, and raffinose and also by L-arabinose and D-xylose.
\end{abstract}

A number of highly specific protein-sugar binding reactions playing important biological functions has been known. Among them are agglutination reactions of red blood cells with their anticera. The reactions involve various problems of biological interest besides their originally ascribed significances. Human blood group $\mathrm{A}, \mathrm{B}$, and $\mathrm{H}$ substances are found not only in red blood cells but also in various mucous glands and the secreted mucus. ${ }^{1 \sim 4}$ Substances with similar serological activities, such as bacterial antigens, ${ }^{5-7}$ and human tumor glycolipids, ${ }^{8,9)}$ are known in other organisms." ${ }^{2 \prime}$ Furthermore, hemagglutinins which are either specific or nonspecific for blood groups are present in various plant and animal tissues. ${ }^{10 \sim 12}$ Recently, some of these hemagglutinins are found to agglutinate certain tumor cells ${ }^{13 \sim 16 /}$ and to initiate mitosis in the culture of normal human leucocytes. ${ }^{17}$

We have found that various kinds of hemagglutinins are produced in large quantities by bacteria and fungi ${ }^{18 ;}$ and that some of them strongly aggregate dissociated sea urchin and sponge cells. ${ }^{19}$ Studies on the structure of blood group substances capable of specifically binding hemagglutinins are required.

We have previously reported ${ }^{20}$ that culture fluids of certain species of Streptomyces decompose serological activities of blood group substances in human saliva and thus interrupt hemagglutination inhibitory action of saliva. In the present report, purification and some characteristics of blood group B substancedegrading enzyme produced by Streptomyces $9917 \mathrm{~S}_{2}$ are described.

\section{MITERIALS AND METHODS}

Strain used and the culture condition. Streptomyces $99175_{2}$ was used throughout the present work. A loopful of spores and mycelia was inoculated into $5 \mathrm{ml}$ of $0.05 \mathrm{M}$ phosphate buffer $(\mathrm{pH} 6.0$ ) containing 20 lactose, $0.5 \%$ peptone (Kyokuto), $0.1 \%$ yeast extract (Difco), and $0.050^{\circ} \mathrm{MgSO}_{4} \cdot 7 \mathrm{H}_{2} \mathrm{O}$, and in cubated for $48 \mathrm{hr}$ at $25^{\circ} \mathrm{C}$ in a test tube with shaking. This was then added into $100 \mathrm{ml}$ of the above medium in a $500-\mathrm{ml}$ llask and culture continued for further $40 \mathrm{hr}$ at $25^{\circ} \mathrm{C}$ with shaking. 
Cells were then removed by filtration through a filter paper (Toyo Roshi, No. 2) and the filtrate was used to isolate $\alpha$-galactosidase.

Assay of glycosidases and blood group $B$ substance-degrading activity. Glycosidase activities were measured as described previously. ${ }^{20}, \mathrm{~B}$ substance-degrading activity was quantitated by the hemagglutination inhibition test as described previously, 20 though microtiter (Taiyo Bussan Co., Ltd., Tokyo) was used in some cases.

Paper chromatography. Galactose liberated from various substrates by the $B$ substance-degrading enzyme was detected by paper chromatography. Samples were placed on a filter paper (Toyo Roshi o. 50). The chromatogram was developed with $n$ butanol: pyridine: water $(6: t: 3)$, and the location of sugars was detected by spraying an ammoniacal solution of silver nitrate. ${ }^{21}$ :

Chemicals. DEAE-Sephadex t-50 and Sephadex G-100 were products of Pharmacia, Uppsala. AntiB serum was obtained from Midori-Juji Co., Ltd., Osaka. Phenyl glycosides were purchased from Sakarai Chemicals, Ltd., Fyoto. Other chemicals were of the purest grades commercially available.

\section{RESULTS}

\section{Glycosidase activities in the culture filtrates}

Effect of various sugars on the production of glycosidases was first examined. Table I shows that $\beta$-galactosidase and $;$-N-acetylglucosaminidase were formed in all cases. $\alpha$ Galactosidase, on the other hand, was detected in lactose or D-galactose containing medium but not in D-glucose containing medium, suggesting that this enzyme is the blood group B substance decomposer.

\section{Purification of a-galactosidase}

Preliminary experiment showed that the amount of enzymes in the culture filtrate was too small to apply the salting-out with ammonium sulfate. Thus the culture filtrate was directly applied to DEAE-Sephadex and the purification of $\alpha$-galactosidase was made as shown in Fig. 1.

Table I. EFfect of Sugar on the Production of Glycosidase Activities IN Streptomyces $9917 \mathrm{~S}$.

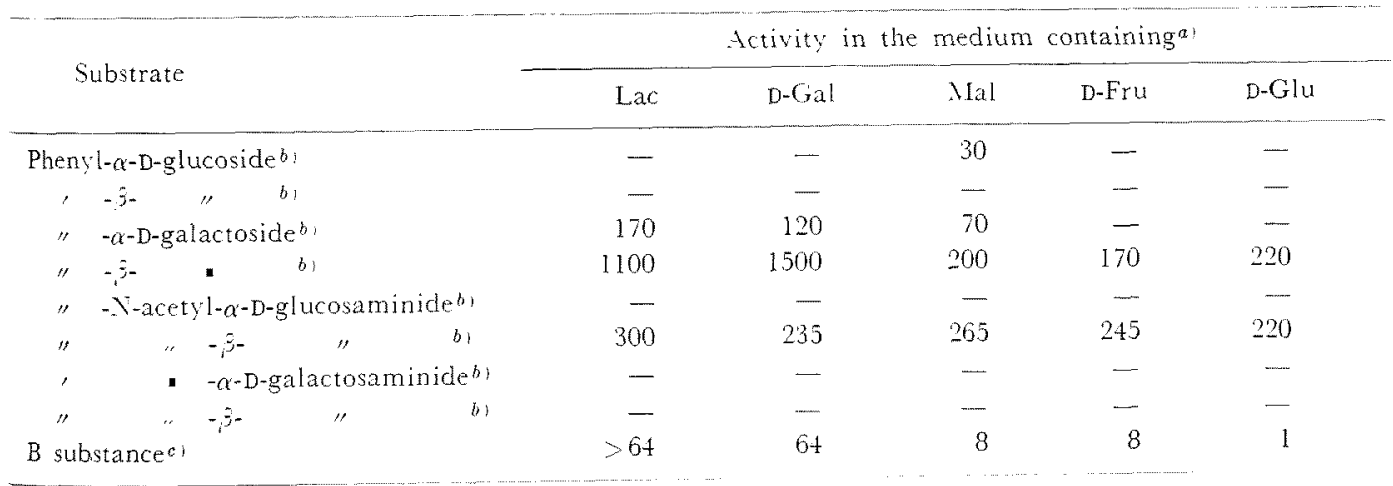

a: 2"ó, each.

b) Absorbance at $660 \mathrm{~m} \%$. One tenth $\mathrm{ml}$ of culture filtrate was mixed with $0.1 \mathrm{ml}$ of $20 \mathrm{~mm}$ phenylglycoside solution in $0.1 \mathrm{M}$ citrate buffer $\left(\mathrm{pH} 6.0\right.$ ) and incubated for $10 \mathrm{~min}$ at $35^{\circ} \mathrm{C}$. At the end of incubation, $0.1 \mathrm{ml}$ of $0.4 \mathrm{M}$ trichloroacetic acid solution, $1.0 \mathrm{ml}$ of $0.4 \mathrm{M} \times \mathrm{aCO}_{3}$ solution, and $0.1 \mathrm{ml}$ of Folin reagent were added in order. After $30 \mathrm{~min}, 1.5 \mathrm{ml}$ of $\mathrm{H}_{2} \mathrm{O}$ was added to the mixture and the amount of the phenol liberated was measured colorimetrically at $660 \mathrm{~m} / \%$.

C. Mirimal amount of $\mathrm{B}$ substance for complete hemagglutination inhibition (1, when heated culture filtrate was used). One twentieth $\mathrm{ml}$ of culture filtrate was mixed with $0.05 \mathrm{ml}$ of $\mathrm{B}$ substance solution and kept at $35^{\circ} \mathrm{C}$. After $6 \mathrm{hr}$, the mixture was heated for $10 \mathrm{~min}$ at $100^{\circ} \mathrm{C}$, and hemagglutination inhibition test was made. 
Culture fluid

filtration through Toyo Roshi No. 2 filter paper

Filtrate, 1.5 liter

adsorption on EDAE-Sephadex A-50 wet 240 $\mathrm{ml}$ ) equilibrated with $0.05 \mathrm{M}$ phosphate buffer $(\mathrm{pH} 6.0)$

elution with $0.05 \mathrm{M}$ phosphate buffer $(\mathrm{pH} 6.0$ ) containing $0.6 \mathrm{M} \mathrm{NaCl}, 400 \mathrm{ml}$

Eluate

concentration with "Dia Filter" G-20T, $2 \mathrm{~kg} / \mathrm{cm}^{2}$ dialysis against $0.05 \mathrm{M}$ phosphate buffer ( $\mathrm{pH} 6.0$ ) at $4^{\circ} \mathrm{C}$, overnight

Dialyzed fraction

DEAE-Sephadex 1-50 column chromatography $(1.6 \times 25 \mathrm{~cm}$, equilibrated with $0.05 \mathrm{M}$ phosphate buffer, pH 6.0)

elution with a linear gradient of $\mathrm{NaCl}$ formed by $200 \mathrm{ml}$ of $0.05 \mathrm{M}$ phosphate buffer ( $\mathrm{pH}$ 6.0 ) and $200 \mathrm{ml}$ of the same buffer containing $0.6 \mathrm{M}>\mathrm{aCl}$

Eluate

concentration and de-salting with a collodion bag

Filtrated fraction

Sephadex G-100 column chromatography ( $2 \times$ $48 \mathrm{~cm}$, equilibrated with $0.05 \mathrm{M}$ phosphate buffer, pH 6.0)

re-chromatography on Sephadex $\mathrm{G}-100(2 \times 48 \mathrm{~cm})$

Purified preparation

Frg. 1. Diagram of Purification Procedures of the $\alpha$-Galactosidase from Streptomyces $9917 \mathrm{~S}_{\mathrm{g}}$.

$\beta$-Galactosidase was almost completely separated from other enzyme activities (pirot experiment, Fig. 2) in the first step (DEAESephadex adsorption) of the purification under the conditions employed.

In practice, 1.5 liter of the culture filtrate was added into $120 \mathrm{ml}$ (wet volume) of
DEAE-Sephadex A-50 equilibrated with 0.05 M phosphate buffer ( $\mathrm{pH} 6.0$ ), the mixture was stirred for $1 \mathrm{hr}$, and filtered under the reduced pressure. The filtrate was added into another $120 \mathrm{ml}$ of DEAE-Sephadex A-50 and treated as above. Two batches of the DEAESephadex A-50 which adsorbed enzymes were then combined and eluted with $400 \mathrm{ml}$ of $0.05 \mathrm{M}$ phosphate buffer $(\mathrm{pH} 6.0$ ) containing $0.6 \mathrm{M} \mathrm{NaCl}$.

The eluate was concentrated to about $20 \mathrm{ml}$ through a "Dia Filter" G-20T (Nippon Shinku Gijutsu Co., Ltd., Chigasaki) with pressure $\left(2 \mathrm{~kg} / \mathrm{cm}^{2}\right.$ with argon gas) and then the concentrate was dialyzed against $0.05 \mathrm{M}$ phosphate buffer ( $\mathrm{pH}$ 6.0). The dialyzed sample was then adsorbed to DEAE-Sephadex A-50 equilibrated with $0.05 \mathrm{M}$ phosphate buffer $(\mathrm{pH} 6.0$ ) in a column $(1.6 \times 25 \mathrm{~cm})$. The column was eluted with a linear gradient of sodium chloride $(0 \sim 0.6 \mathrm{M})$ in the above phosphate buffer. Fractions $(5 \mathrm{ml}$ each) were collected. All the operations were carried out at $4^{\circ} \mathrm{C}$.

Figure 3 shows the elution pattern of the dialyzed enzyme fraction through the DEAESephadex A-50 column. $\beta$-Galactosidase activity was further removed, but $\alpha$-galactosidase and $\beta-N$-acetyl-glucosaminidase were not separated from each other. Thus fractions $21 \sim$ 35 were combined, concentrated in a collodion bag to less than $1 \mathrm{ml}$. The concentrate was applied to a Sephadex G-100 column $(2 \times 48 \mathrm{~cm})$ equilibrated with $0.05 \mathrm{M}$ phosphate buffer. The column was eluted and fractions were

Table II. Summary of the Purification of $\alpha$-Galactosidase from Streptomyces 9917. 2

\begin{tabular}{lrrrrc}
\hline \multicolumn{1}{c}{ Procedure } & $\begin{array}{c}\text { Protein } \\
\left(\mathrm{mg}^{b}\right)\end{array}$ & $\begin{array}{c}\alpha \text {-Galactosidase activity } \\
\left(\mathrm{U}^{a}\right)\end{array}$ & $\begin{array}{c}\text { Yield } \\
(\mathrm{U} / \mathrm{mg})\end{array}$ & $\begin{array}{c}\text { Purification } \\
\text { ratio }\end{array}$ \\
\hline Culture filtrate & 2210 & 51840 & 22.4 & 100 & 1 \\
DEAE-Sephadex A-50 (1st) & 738 & 24720 & 33.5 & 47.7 & 1.49 \\
DEAE-Sephadex A-50 (2nd) & 270 & 14040 & 52.0 & 27.1 & 2.32 \\
Sephadex G-100 (1st) & 43.2 & 7200 & 166.7 & 13.9 & 7.44 \\
Sephadex G-100 (2nd) & 15.6 & 5040 & 323.1 & 9.7 & 14.4 \\
\hline
\end{tabular}

a) 1 amole phenol/10 min.

b) Determined by the methed of Lowry and Folin. 


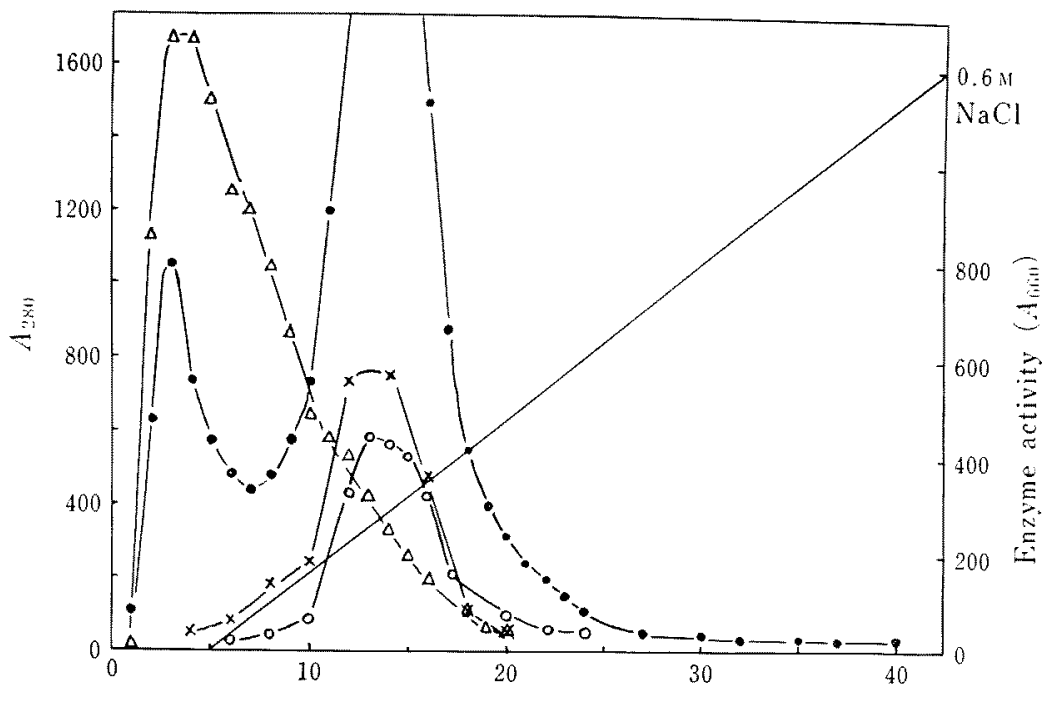

Tube number

FIG. 2. DEAE-Sephadex Chromatography of the Culture Filtrate of Streptomyces $9917 \mathrm{~S}_{2}$.

One liter of culture filtrate was concentrated to about $50 \mathrm{ml}$ with "Diamilter" G-20T and the concentrate was applied to a $2 \times 25 \mathrm{~cm}$-column of DEAE-Sephadex A-50.

- Absorbance at $280 \mathrm{~m} /:$.

O-O $\alpha$-Galactosidase activity.

$\triangle-\triangle \beta$-Galactosidase activity. $\quad x-x \quad \beta$-N-Acetyl-glucosaminidase activity.

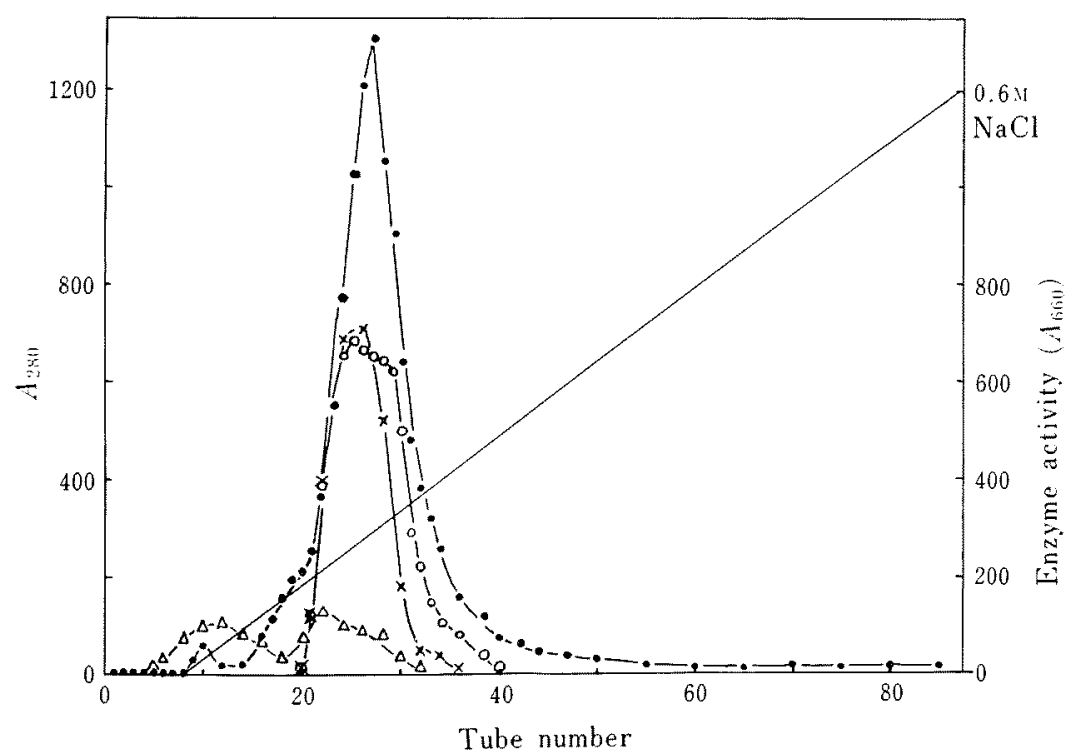

FIG. 3. The Second DEAE-Sephadex Chromatography.

- Absorbance at $280 \mathrm{~m} \%$. $\quad 0$ - 0 -Galactosidase activity.

$\triangle-\Delta \beta$-Galactosidase activity. $\quad x-x \quad \beta$-N-Acetyl glucosaminidase activity. 


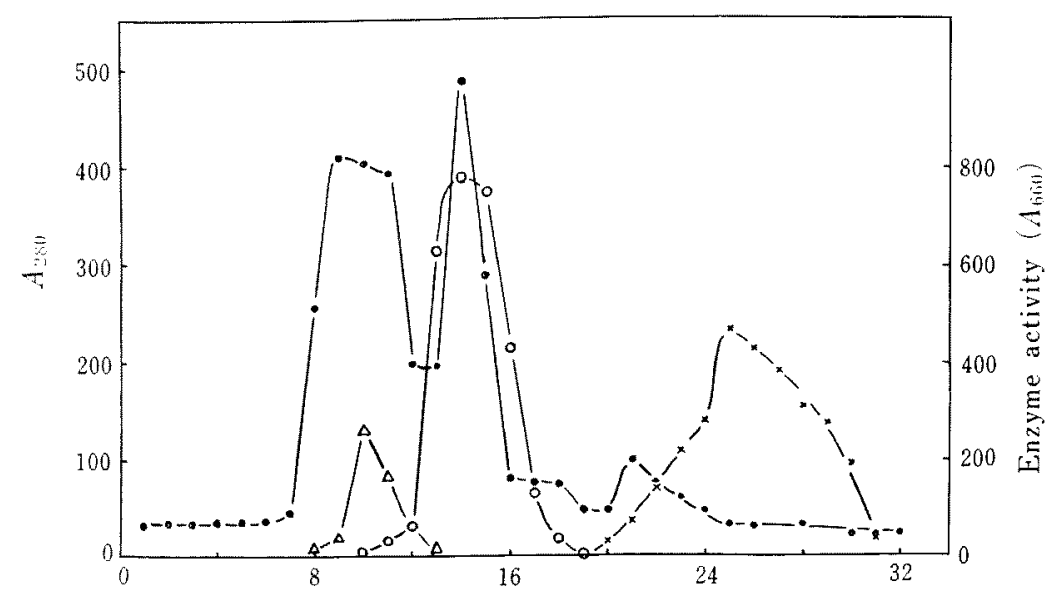

Tube number

FIG. 4. The First Sephadex G-100 Chromatography of Purified $\alpha$-Galactosidase.

- Absorbance at $280 \mathrm{~m} /$. $\Delta-\triangle \quad j$-Galactosidase activity.

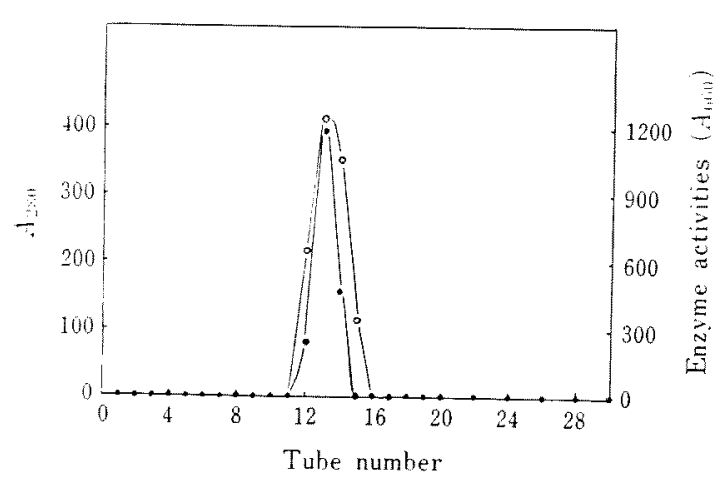

FIG. 5. The Second Sephadex G-100 Chromatography of Purified a-Galactosidase.

- Absorbance at $280 \mathrm{~m} \mu$.

a-Galactosidase activity.

collected as above. As shown in Fig. 4, $\alpha$ galactosidase and $\beta$-N-acetyl-glucosaminidase activities were completely separated by this procedure, and the blood group B substancedegrading activity was observed only in the $\alpha$-galactosidase fraction. Re-chromatography of the $\alpha$-galactosidase fraction (fractions $12 \sim$ 17) on the same Sephadex G-100 column resulted in a single symmetrical peak of $\alpha$ -
O-O $\alpha$-Galactosidase activity.

$x-x \quad 3-N$-Acetyl-glucosaminidase activity.

galactosidase activity (Fig. 5).

Table II summarizes the results. Specific activity of the $\alpha$-galactosidase was increased 15 -fold over the culture filtrate.

\section{Properties of the purified a-galactosidase}

Using the $\alpha$-galactosidase preparation purified as above, properties of the enzyme were

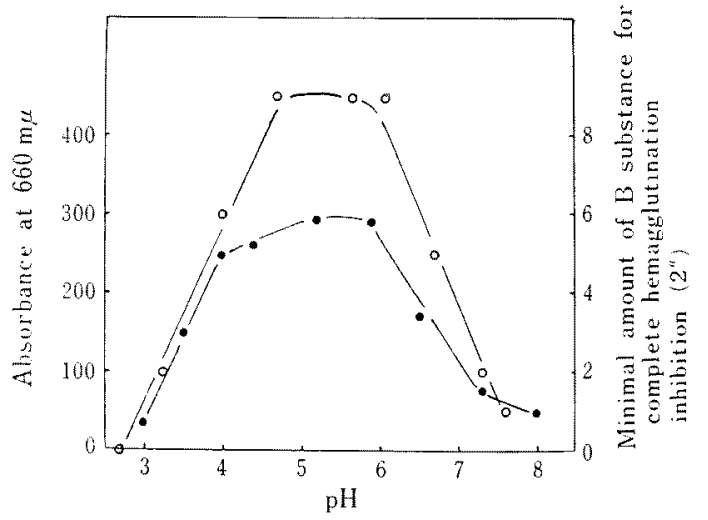

FIG. 6. pH-Activity Curves of the Purified Enzyme.

O- $\mathrm{B}$ substance degradation (Heated enzyme, $n=0$ ).

- Phenyl-a-D-galactoside hydrolysis. 
investigated, especially with regard to the blood group B substance-degrading activity. Assay procedures for glycosidase and $B$ substance-degrading activities were as previously described $^{20}$ except that $0.05 \mathrm{ml}$ of the puri-

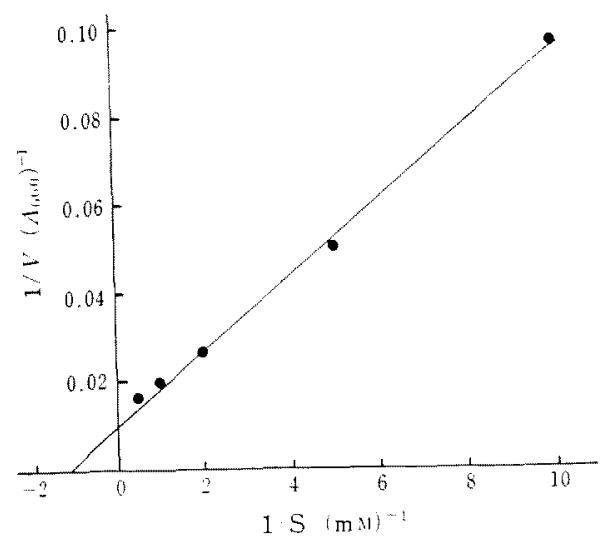

FIg. 7. Linewearer-Burk Plot of the Purified Enzrae for Phenvl-a-gatactoside. ( $\mathrm{pH} 6.0,35 \% \mathrm{C}$ )

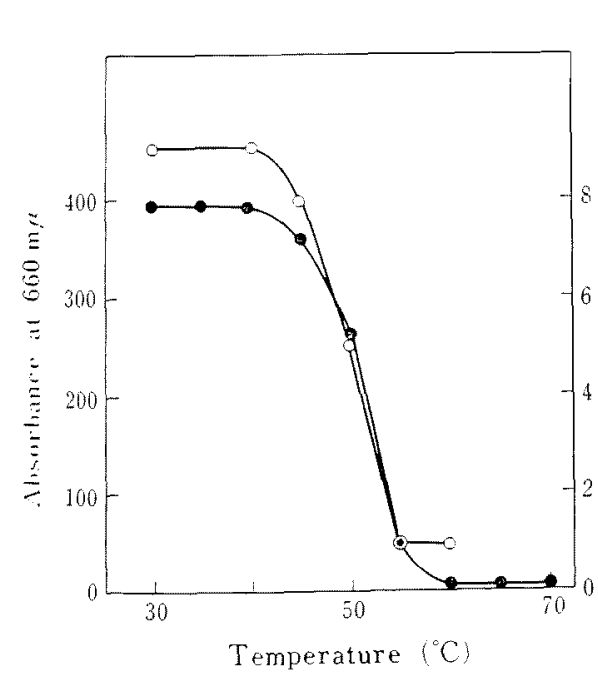

FIG. 8. Thermal Stability of the Purified Enzyme.

Enzyme preparations were heated for $10 \mathrm{~min}$, cooled, and the activities remained were measureed.

O-O B substance degradation (Heated enzyme, $n=0$ ).

-- Pheny-l-a-Dalactoside hydrolysis. fied enzyme preparation $(0.2 / \mathrm{g}$ protein), instead of $0.2 \mathrm{ml}$ of the culture filtrate, was used in the present study. Under these conditions, the rate of hydrolysis was proportional to the amount of protein up to $0.4 \mu \mathrm{g}$.

As shown in Fig. 6, the optimal $\mathrm{pH}$ was found to be $4.5 \sim 6.0$ for both $\alpha$-galactosidase and $\mathrm{B}$ substance degrading activities. The $\mathrm{Km}$

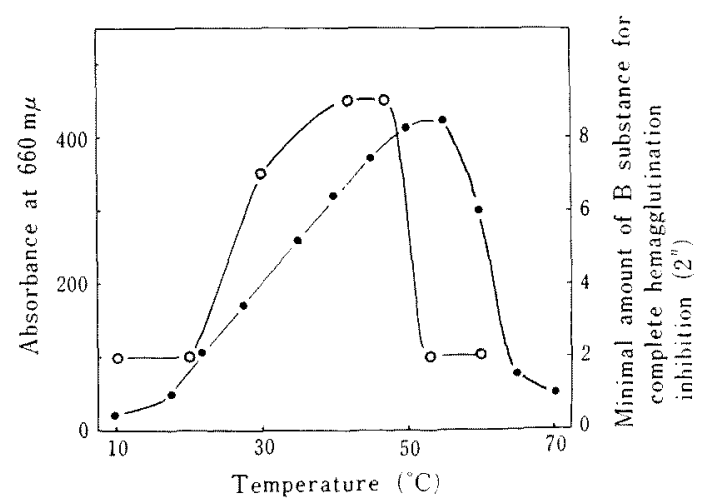

FIG. 9. Temperature-Activity Curves of the Purified Enzyme.

- - B substance degradation, (Heated enzyme. $n=0)$.

- Phenyl- $\alpha$-D-galactoside hydrolysis.

TABLE III. EFFECT OF INHIBITORS ON THE ENZYME ACTIVITIES

\begin{tabular}{|c|c|c|}
\hline & & Activity \\
\hline Inhibitor & $\left(\times 10^{-3} \mathrm{M}\right)$ & $\begin{array}{l}\text { B Sub- Phenyl-a-D- } \\
\text { stance de- galactoside } \\
\text { gradationa hydrolysis }\end{array}$ \\
\hline
\end{tabular}

\begin{tabular}{lrrr}
\hline None & - & 512 & 185 \\
EDT. & 10 & 512 & 190 \\
Iodoacetate & 1 & 256 & 110 \\
$p$-CMB & 0.1 & 2 & 60 \\
$\mathrm{NaCN}$ & 1 & 256 & 205 \\
NaNi & 1 & 256 & 190 \\
NaF & 3 & 512 & 195 \\
$\alpha, \alpha^{\prime}$-Dipyrid! & 1 & 256 & 185 \\
N-Ethylmaleimide & 1 & 512 & 190
\end{tabular}

a) Minimal amount of $B$ substance for complete hemagglutination inhibition ( 1 , when heated enzyme was used).

b. Absorbance at $660 \mathrm{mu}$. Sec the footnote in Table I. 
value of the enzyme for phenyl- $\alpha$-galactoside was $1<10^{-3} \mathrm{M}$ (Fig. 7).

The enzyme was unstable at temperatures higher than $45^{\circ} \mathrm{C}$, and heating at $55^{\circ} \mathrm{C}$ for 10 min resulted in the complete loss of the activities (Fig. 8). In the presence of the substrate, however, the maximum $\alpha$-galactosidase activity was found at $50 \sim 55^{\circ} \mathrm{C}$, while the highest $\mathrm{B}$ substance degrading activity was at $40 \sim 50^{\circ} \mathrm{C}$ (Fig. 9). The difference is probably due to the different incubation period in assay procedures ( $10 \mathrm{~min}$ vs. $8 \mathrm{hr}$. see Methods).

The activities of $\alpha$-galactosidase and $B$ substance degradation were inhibited with $p$ chloromercuribenzoate ( $p$-CMB). Monoiodoacetate at the concentration of $110^{-3} \mathrm{M}$ also inhibited the enzyme activities. (Table III). Among the metallic ions examined, $\mathrm{Ag}^{+}$and $\mathrm{Hg}^{2+}$ at the concentration $5 \times 10^{-4} \mathrm{M}$ inhibited the enzyme activities (Table IV). These results suggest that the activities are mediated by SH-enzyme.

TABLE IV. EFFECT OF METALLIC IONS ON THE ENZYME ACTIVITIES

\begin{tabular}{|c|c|c|c|}
\hline \multirow[b]{2}{*}{ Metal } & \multirow[b]{2}{*}{$\begin{array}{l}\text { Concentration } \\
\left(\therefore 10^{-4} \mathrm{M}\right)\end{array}$} & \multicolumn{2}{|c|}{ Activity } \\
\hline & & $\begin{array}{l}\text { B Substance } \\
\text { degra- } \\
\text { dationd }\end{array}$ & $\begin{array}{l}\text { Phenyl- } \alpha-\mathrm{D}- \\
\text { galactoside } \\
\text { hydrolysis }\end{array}$ \\
\hline Xone & - & 512 & 185 \\
\hline $\mathrm{Ag}$ & 5 & 8 & $1+5$ \\
\hline $\mathrm{Ba}^{2-}$ & 5 & 512 & 190 \\
\hline $\mathrm{Ca}^{2-}$ & 5 & 512 & 190 \\
\hline $\mathrm{Co}^{\circ-}$ & $j$ & 256 & 190 \\
\hline $\mathrm{Cu}^{2}+$ & $j$ & 512 & 200 \\
\hline $\mathrm{Fe}^{3-}$ & 5 & 512 & 185 \\
\hline $\mathrm{Hg}^{2}$ & 5 & 8 & 30 \\
\hline $\mathrm{Mg}^{2-i}$ & 5 & 512 & 195 \\
\hline $\mathrm{Mn}^{2--}$ & 5 & 512 & 240 \\
\hline $\mathrm{Ni}^{2+}$ & 5 & 512 & 190 \\
\hline $\mathrm{Pb}^{2-}$ & 5 & 512 & 200 \\
\hline $\mathrm{Sn}^{--}$ & 5 & 512 & 190 \\
\hline $\mathrm{Zn}^{2 \div}$ & 5 & 312 & 190 \\
\hline
\end{tabular}

a) Minimal amount of $B$ substance for complete hemagglutination inhibition ( 1 , when heated enzyme was used).

b) Absorbance at $660 \mathrm{~m} / 1$.
Eleven sugars and 2 aminosugars were tested for their effects on the enzyme reactions. Galactose and galactose-containing sugars such as melibiose, raffinose, and D-galactosa-

Table V. EFFect of Sugars on the ENzyme Activities

\begin{tabular}{lcrc}
\hline & & \multicolumn{2}{c}{ Activity } \\
\cline { 3 - 4 } Sugar & Concentration & $\begin{array}{c}\text { B Substance } \\
\text { degra- } \\
\text { dation }\end{array}$ & $\begin{array}{c}\text { Phenyl- } \alpha \text {-D- } \\
\text { galactoside } \\
\text { hydrolysis }\end{array}$ \\
\hline None & - & 512 & 150 \\
L-Ara & 33 & 4 & 70 \\
D-Fru & 33 & 512 & 150 \\
D-Gal & 33 & 4 & 10 \\
D-Glu & 33 & 512 & 150 \\
D-Man & 33 & 512 & 150 \\
Mel & 33 & 4 & 35 \\
Raf & 33 & 4 & 80 \\
L-Rha & 33 & 512 & 150 \\
D-Rib & 33 & 512 & 150 \\
L-Sor & 33 & 256 & 150 \\
D-Xyl & 33 & 4 & 30 \\
D-GalN & 33 & 16 & 125 \\
D-GluN & 33 & 512 & 200 \\
\hline
\end{tabular}

a) Minimal amount of $\mathrm{B}$ substance for complete hemagglutination inhibition ( 1 , when heated enzyme was used).

b) Absorbance at $660 \mathrm{~m} \mu$.

TABLE VI. ANOMERIC SPECIFICITY OF THE $\alpha$-GALACTOSIDASE of Streptomyces $9917 \mathrm{~S}_{2}$

Incubation was made with $2 \mu \mathrm{g}$ enzyme protein, at $\mathrm{pH} 6.0$ and at $35^{\circ} \mathrm{C}$.

\begin{tabular}{lc}
\multicolumn{1}{c}{ Substrate } & Degradation $^{a}$ \\
\hline Phenyl- $\alpha$-D-galactoside & + \\
Phenyl- $\beta$-D-galactoside & - \\
Phenyl-N-acetyl- $\alpha$-D-galactosaminide & - \\
Phenyl-N-acetyl- 3 -D-galactosaminide & - \\
Lactose & - \\
Melibiose & + \\
Raffinose & + \\
B substance & + \\
\hline
\end{tabular}

a) At the end of incubation, $0.01 \mathrm{ml}$ of the reaction mixture was applied to paper chromatography, and the galactose liberated from substrates was determined qualitatively. 
mine were all inhibitory. L-Arabinose and D-xylose were also inhibitory, while other sugars tested were not (Table V).

Table VI shows the substrate specificity of the purified enzyme. Melibiose and raffinose were hydrolyzed besides phenyl- $\alpha$-galactoside and the $B$ substance, indicating that the enzyme cleaves $\alpha$-(1 $1 \rightarrow 6)$-galactosidic linkage as well as $\alpha-(1 \rightarrow 3)$-galactosidic linkage.

\section{DISCLSSION}

Relatively little is known on $\alpha$-galactosidase, ${ }^{221}$ compared to 3 -galactosidase. In bacteria, the presence of $\alpha$-galactosidase activity has been reported only with Aerobacter aerogenes, ${ }^{231}$ Diplococcus pneumoniae, ${ }^{241}$ Streptococcus bovis, ${ }^{251}$ Streptomyces olivaceus, Str. fradiae, Str. roseospinus nov. sp. ${ }^{26,27)}$ Escherichia coli, ${ }^{28,291}$ and some soil bacteria. ${ }^{30}$ Main concern in these studies was to elucidate the bacterial enzymes which hydrolyze raffinose and melibiose. The $\alpha$-galactosidases from these bacteria effectively cleave $\alpha$ - $(1 \rightarrow 6)$-galactosidic linkages of the above sugars, but whether the enzymes are also able to cleave other $\alpha$-galactosidic linkages has been left unclear.

Serological activity of blood group B substances derives from $\alpha-(1 \rightarrow 3)$-galactosidic linkage at the nonreducing terminal of blood group mucopolysaccharides, ${ }^{31 \prime}$ and the B substance-degrading enzymes are $\alpha$-galactosidases which cleave this linkage..$^{32,331}$

The $\alpha$-galactosidase from coffee beans hydrolyzes both raffinose $(\alpha-(1 \rightarrow 6)$-galactosidic linkage) and the $B$ substance $(\alpha-(1 \rightarrow 3)$-linkage). ${ }^{341}$ On the other hand, $\alpha$-galactosidases from yeast, sweet almonds, Plattela vulgata, ${ }^{331}$ Mortierella vinacea $a^{35}$ cleave only $\alpha-(1 \rightarrow 6)$ linkage. Bacterial B substance-degrading enzymes have not been examined for their ability to hydrolyze $\alpha-(1 \rightarrow 6)$-linkage.

In the present study, we have attempted to characterize the $\alpha$-galactosidase of Streptomyces $9917 \mathrm{~S}_{2}$, especially to elucidate whether the enzyme cleaves $\alpha-(1 \rightarrow 3)$-galactosidic linkage.
First, it was found that the $B$ substance degrading activity is inducible by lactose (a $\beta-$ galactoside) as $\alpha$-galactosidase is. Generally, bacterial $\alpha$-galactosidases are inducible enzymes $^{23,28,36-381}$ except in the case of $S$. bovis. ${ }^{25}$ However, it has not been studied whether bacterial B substance-degrading enzymes are inducible. $\alpha$-Galactosidases are induced both by $\alpha$ - and $\beta$-galactosides in $E$. coli $\mathrm{B},{ }^{28}$ Str. olivaceus, ${ }^{36)}$ and bacterium $\mathrm{M} 12{ }^{371}$ but only by $\alpha$-galactosides in $A$. aerogenes ${ }^{231}$ and $E$. coli IAM $1277 .^{38}$

Purification of the a-galactosidase from Streptomyces $9917 \mathrm{~S}_{2}$ has also resulted in the purification of the blood group B substancedegrading activity, both activities falling into the same fraction throughout the purification processes. The final preparation, which was 15-fold enriched in the specific activity of $\alpha$ galactosidase, was free from $\alpha$ - and $\beta$-glucosidases, $\beta$-galactosidase, $\alpha$ - and $\beta$-glucosaminidases, and $\alpha$ - and $\beta$-galactosaminidases.

Several bacterial $\alpha$-galactosidases have so far been purified,,$^{39-42}$ but purification of bacterial B substance-degrading enzymes has not been made except for partial purification of the enzyme from Clostridium maebashi. ${ }^{321}$ Some bacterial $\alpha$-galactosidases have been reported to be unstable in various purification procedures. $^{23,41,421}$ The $\alpha$-galactosidase of Streptomyces $9917 \mathrm{~S}_{2}$ was, however, quite stable and isolated in a highly purified state.

Properties of the purified $\alpha$-galactosidase preparation examined in the present study indicate that the activities of $\alpha$-galactosidase and $B$ substance degradation is attributed to the same enzyme protein. The enzyme has a broad optimal $\mathrm{pH}$ range, $4.5 \sim 6.0$, for both reactions. This value corresponds to that reported for $\alpha$-galactosidases from many other organisms, though some of a-galactosidases have been reported to possess their optimal $\mathrm{pH}$ values ranging from 6.5 to $8.2^{4 .^{4 \sim 44}}$

The activities of $\alpha$-galactosidase and the $\mathrm{B}$ substance degradation from Streptomyces $9917 \mathrm{~S}_{2}$ were inhibited by D-galactose, melibiose, and 
raffinose, and also by L-arabinose and D-xylose. The first three sugars are probably acting as competitive inhibitors. These sugars are also reported to be inhibitory on the $\mathrm{B}$ substancedegrading enzyme of $\mathrm{Cl}$. maebashi. ${ }^{44}$ However, further investigation will need for the elucidation for inhibition by L-arabinose and D-xylose. $\alpha$-Galactosidases from plants, yeasts, and molds have been known to have $\beta-L$ arabinosidase activity. ${ }^{22}$ The crystalline $\alpha$ galactosidase of $M$. vinacea hydrolyzes methyl$\beta$-L-arabinoside. ${ }^{35} \quad$ This may be the case with the enzyme from Streptomyces $9917 \mathrm{~S}_{2}$. Inhibition by $D$-xylose may have more difficulty to explain, although there is a report that the $\alpha$-galactosidase activity of $M$. vinacea is inhibited by $D$-xylose. ${ }^{35 \text { ? }}$

Present study has shown that $a$-galactosidase from Streptomyces $9917 \mathrm{~S}_{2}$ cleaves $\alpha-(1 \rightarrow 6)$ - and $\alpha-(1 \rightarrow 3)$-galactosidic linkages. It is now under investigation with a further purified enzyme preparation whether this enzyme can cleave other $\alpha$-galactosidic linkages.

Addendum: Taxonomical characteristics of Streptomyces $9917 \mathrm{~S}$. will be reported by Dr. A. Shimazu of the Institute of Applied Microbiology, University of Tokyo, in the near future.

Acknowledgement. The authors would like to express their thanks to Dr. $\mathrm{T}$. Fomiyama of the Faculty of Medicine. University of Tokyo, for his helpful advices in serological techniques.

\section{REFERENCES}

1) E..1. Kabat, "Blood Group Substances," Academic Press Inc., New York, 1956.

2) G. F. Springer, "Ciba Foundation Symposium on the Chemistry and Biology of Mucopolysaccharides," J. and A. Churchill Ltd., London, 1958, p. 216.

3) V. Hiyama and S. Sasaki, "Tato-Seikagaku," Vol I, ed. by F. Egami et al., Kyoritsu Shuppan, Tokyo, 1970, p. 475.

4) G. Hartmann, "Group Antigens in Human Organs," Munksgaard Copenhagen, 1941.
5) M. Eisler, Z. Immunitats, 67, 38 (1930).

6) T. Furuhata, "Ketsuekigata-Gaku," Igaku Shoin, Tokyo, 1957, p.169.

7) G.F. Springer, E.T. Wang, J.H. Nichols and J. M. Shear, Ann. N. Y. Acad. Sci, 133, $566(1966)$.

8) S. Hakomori, "Tato-Seikagaku," Vol II, ed. by. F. Egami et al., Kyoritsu Shuppan, Tokyo, 1970, p. 1118.

9) S. Hakomori, Seikagaku, 43, 113 (1971).

10) W.C. Boyd and R.M. Reguera, J. Immunol.,62, 333 (1949).

11) K.O. Renkonen, Ann. Med. Exptl. Fenn., 26, 66 (1948).

12) T. Osawa, Tampakushitsu Kakusan Koso, 16, 335 (1971).

13) J. C. Aub, C. Tieslau and A. Lankester, Proc. Natl. Acad. Sci., U. S., 50, 613 (1963).

14) S. Hakomori, J. Koscielak, K.J. Bloch and R. W. Jeanloz, J. Immunol., 98, 31 (1967).

15) M. M. Burger and A. R. Goldberg, Proc. Natl. Acad. Sci., U. S., 57, 359 (1967).

16) M. Inbar and L. Sachs, ibid., 63, 1418 (1969).

17) P.C. Nowell, Cancer Res., 20, 462 (1960).

18) Y. Fujita, K. Oishi and K. Aida, J. Gen. Appl. Microbiol., in press.

19) I. Fujita, K. Oishi and K. Aida, ibid., in press.

20) K. Oishi and K. Aida, Agr. Biol. Chem., 35, 1101 (1971).

21) S.M. Partridge, Biochem. J., 42, 238 (1948).

22) K. Wallenfels and O.P. Malhotra, Adv. Carbohyd. Chem., 16, 239 (1961).

23) D. S. Hogness and E. H. Battley, Fed. Proc., 16, 197 (1957).

24) Y.-T. Li, S.-C. C. Li and M. R. Shetlar, Arch. Biochem. Biophys., 103, 436 (1963).

25) R.W. Bailey, Biochem. J., 86, 509 (1963).

26) H. Suzuki and O. Tanabe, Nippon Nogeikagaku Kaishi, 37, 623 (1963).

27) H. Suzuki, I. Ozawa and O. Tanabe, ibid., 38, $334(196 t)$.

28) C.J. Porter, R. Holmes and B. F. Crocker, J. Gen. Phys., 37, 271 (1953).

29) S. Kawamura, T. Miyake and T. Narasaki, Kagawa-Daigaku Nogakubu Gakujutsu-Hokoku, 20, 25 (1968).

30) S. Sugawara and T. Sato, Obihiro-Chikusandaigaku Gakujutsukenkyu-Hokoku, 4, 477 (1967).

3I) T.J. Painter, W.M. Watkins and W.T.J. Morgan, Nature, 206, 594 (1965).

32) S. Iseki, K. Furukawa and S. Yamamoto, Proc. Japan Acad., 35, 513 (1959). 
33) W.M. Watkins, M.L. Zarnitz and E. A. Kabat, Nature, 195, 1204 (1962).

34) M.L. Zamitz and E.A. Kabat, J. Am. Chem., Soc., 82, $3953(1960)$.

35) H. Suzuki, S.-C. Li and Y.-T. Li, J. Biol. Chem., 245. $781(1970)$.

36) H. Suzuki, I. Ozawa and O. Tanabe, Nippon Nogeikagaku Kaishi, 38, 542 (1964).

37) T. Sato, M. Hosokawa and S. Sugawara, ObihiroChikusandaigaku Gakujutsukenkyu-Hokoku, 6. 417 (1970).

38) S. Kawamura, H. Torigoe and T. Kasai, KagawaDaigaku Yogakubu Gakujutsu-Hokoku, 21, 104 (1970).

39) I.-T. Li and M. R. Shetlar, Arch. Biochem. Biophys., 108, 301 (1964).
40) H. Suzuki, Y. Ozawa and O. Tanabe, Agr. Biol. Chem., 30, 1039 (1966).

41) S. Kawamura, T. Kasai and S. Tanushi, Abstracts of Papers, 39th Annual Meeting of Agr. Chem. Soc. Japan, Nagoya, April, 1968. p. 213.

42) T. Sato and S. Sugawara, Abstracts of Papers, 42nd Annual Meeting of Agr. Chem. Soc. Japan, Tokyo, April, 1971, p.245.

43) S. Iseki and T. Ikeda, Proc. Japan Acad., 32, 201 (1956).

4) S. Iseki, K. Furukawa and S. Yamamoto, ibid., 35, 507 (1959).

45) O.P. Bahl and K.M.L. Agrawal, J. Biol. Chem., 244, 2970 (1969). 